Посвящается светлой памяти ученого-нефтехимика, основателя журнала «Нефть и газ»,

Надирова Надира Каримовича

\title{
ТЕХНИКО-ЭКОНОМИЧЕСКИЙ ЭФФЕКТ НИЗКОТЕМПЕРАТУРНОЙ ГИДРОКОНВЕРСИИ НЕФТЯНОГО СЫРЬЯ
}

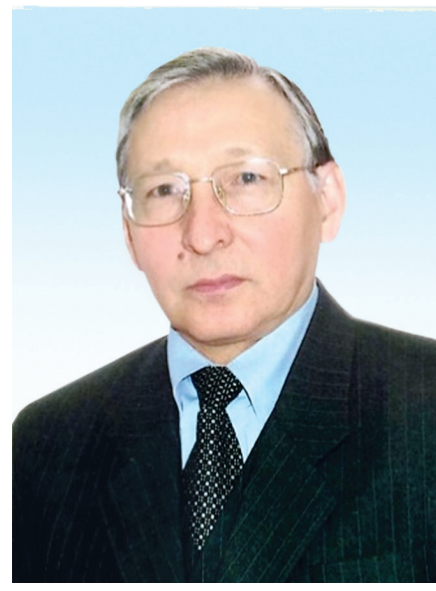

А.А. КАЛЫБАЙ доктор физ.-мат. наук, професссор, академик МИА и НИА РК, https://orcid.otg/0000-0002-7646-8991

\section{АО «КАЗАХСТАНСКИЙ ДОРОЖНЫЙ НАУЧНО-ИССЛЕДОВАТЕЛЬСКИЙ ИНСТИТУТ» 050061, г. Алматы, ул. Нурпеисова, 2A}

Низкотемпературная (не выше $+70^{\circ} \mathrm{C}$ ) вакуумно-волновая гидроконверсия нефрти, включая битуминозную нефть типа 4 по ГОСТ Р 51858-2012, природный нефттебитум (ПНБ), тяжелые, темные, вторичные нефттеотходы типа кислые гудроны, нефтешламы и жидкие отходы коксохимических производств, в топлива жидкие дистиллятные со светлыми фрракциями не менее 92\% массовых, серой не больше 0,02\%, очищенные от всех видов гетероатомов, позволяет в десятки раз увеличить углеводородный экспортный потенциал страны. Учитывая эти составляющие технико-экономического потенциала гидроконверсии нефтяного сырья, рассчитаем общие выгоды нефтедобывающей, нефтетранспортирующей и нефтеперерабатывающей отрасли Казахстана.

КЛЮЧЕВЫЕ СЛОВА: атмосферная перегонка, вакуумная перегонка, гидроочистка, каталитический крекинг, гидрокрекинг, вакуумный газойль, водородосодержащие газы, водород, коксовые отложения, гидроконверсия, глубина переработки, безвозвратные потери, восполнение потерь, доход, рентабельность.

\footnotetext{
* Адрес для переписки. E-mail: innatechastana@gmail.com
} 


\section{МҰНАЙ ШИКІЗАТЫНЫҢ ТӨМЕН ТЕМПЕРАТУРАДАҒЫ ГИДРОКОНВЕРСИЯНЫҢ ТЕХНИКАЛЫҚ-ЭКОНОМИКАЛЫҚ ТИІМДІЛІГІ}

А.А. КАЛЫБАЙ, фризика-математика ғылымдарының докторы, профессор, Халықаралық инженерлік академиясының, Қазақстан Республикасының Ұлттық инженерлік академиясының академигі, https://orcid.otg/0000-0002-7646-8991

\section{«ҚАЗАҚСТАН ЖОЛ ҒЫЛЫМИ-ЗЕРТТЕУ ИНСТИТУТЫ» АҚ 050061, Алматы қ, Нурпеисов қ, 2А}

Еліміздің мұнай экспорттық потенциалын 4-інші типті битумдық мұнайды (ГОСТ P 51858-2012), табиғи мұнай битумын, екінші реттегі қара, ауыр мұнай өнімдерін (қышқыл гудрон тәрізді), мұнай қалдықтарын жіне коксохимиялық өндірістің сұйық қалдықтарын төмен температурада $\left(+75^{\circ} \mathrm{C}\right.$ жоғары емес) вакуум-толқынды гидроконверсиялаумен мөлдір фрракциялары 92\% төмен емес, күкүрті 0,02\% төмен, барлық гетероатомдардан тазаланған сұйық дистиллят отын алу арқылы ондаған есе көтеруге мүмкіндік бар. Осы әдістің мұнай шикізаттарын гидроконверсиялаудағы технико-экономикалық басымдылығын ескеріп, Қазақстанның мұнай өндіру, тасымалдау және өңдеу саласының айтылған әдісін пайдаланбауынан туындайтын шығындардың естеуі берілді.

ТҮЙІн СӨзДЕР: атмосфрералық өңдеу, вакуумдық өңдеу, гидротазалау, катализдік крекинг, гидрокрекинг, вакуум газойлы, сутегі араласқан газдар, сутегі, кокстың отыруы, гидроконверсиялау, өңдеу тереңдігі, қайтарлымсыз жоғалтулар, жоғалтуды орнына келтіру, өнім, рентабельділік.

\section{TECHNICAL AND ECONOMIC EFFECT OF LOW TEMPERATURE HYDRO CONVERSION OF OIL RAW MATERIALS}

A.A. KALYBAY, Doctor of Physical and Mathematical Sciences, Professor, Academician of the International Engineering Academy and the National Engineering Academy of the Republic of Kazakhstan, https://orcid.otg/0000-0002-7646-8991

KAZAKHSTAN HIGHWAY RESEARCH INSTITUTE JSC

2A, Nurpeisov str., Almaty, 050061, Republic of Kazakhstan

Low-temperature (no higher than $+70^{\circ} \mathrm{C}$ ) vacuum-wave hydroconversion of oil, including butiminose oil of type 4 according to GOST R 51858-2012, natural petroleum bitumen (NPB), heavy, dark, secondary oil waste such as acid sludge, oil sludge and liquid waste of coke production into liquid fuels distillate with light fractions not less than $92 \%$ by weight, sulfur not more than $0.02 \%$, purified from all types of heteroatoms, allows to increase the hydrocarbon export potential of the country tenfold. Without touching upon these components of the technical and economic potential of the hydroconversion of crude oil, we will calculate the total benefits of the oil-producing, oil-transporting and oil-refining industries of Kazakhstan.

KEY WORDS: atmospheric distillation, vacuum distillation, hydrotreating, catalytic cracking, hydrocracking, vacuum gas oil, hydrogen-containing gases, hydrogen, coke deposits, hydroconversion, processing depth, irrecoverable losses, loss replacement, income, profitability.

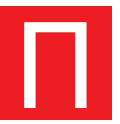

равительство страны приняло (март, 2021 г.) «Экологический кодекс Республики Казахстан» (Экокодекс РК) с основопологающими принципами, такими как «Загрязнитель внедряет наилучшие доступные технологии» (НДТ), «Загрязнитель платит за эмиссию парниковых газов» (ПГ), «Загрязнитель платит и исправляет» и др. [1]. Экокодекс РК называет нефтяную, угольную и энергетическую 
отрасли основными загрязнителями окружающей среды и считает, что на их доли приходятся около 70 \% эмиссии ПГ. На самом деле, по «Модели мировой экономики на период до 2030 года» (ММЭ-2030) Международного энергетического агентства (МЭА) [2], на мазуте вырабатываются 40 \% объема электрической и тепловой энергии, потребленной мировой экономикой. В то же время не следует забывать, что мазут это вторичный нефтепродукт нефтеперерабатывающей отрасли (НПО).

Тогда главным загрязнителем окружающей среды, в конечном счете, выступает НПО. По нашему мнению, для НПО в качестве НДТ могла бы выступать технология низкотемпературной (не выше $+70{ }^{\circ} \mathrm{C}$ ) вакуумно-волновой гидроконверсии нефтяного сырья на экологически чистое топливо жидкое дистиллятное (ТЖД), содержащее не менее 92\% массовых светлых фракций (бензин, керосин и дизель), очищенное от серы до $0,02 \%$ и полностью от всех видов гетероатомов и соединений, плюс обеспечивающее выход маловязкого судового топлива в $12 \%$ массовых. Иначе говоря, НПО, внедряя указанную технологию гидроконверсии, могла бы достичь рекордной глубины переработки не только средней товарно-экспортной нефти (тип 2 по ГОСТ Р 51858-2012 [3]), но и более доступных, дешевых и создающих экологические проблемы видов нефтяного сырья [4-7]. Об этом с болью сердца написал академик Н.К. Надиров в статье [8].

В связи с вышеуказанными показателями выхода моторных и судовых топлив (104\%) на нефть, следует отметить, что прирост углеводородной массы сырья объясняется особенностью технологии гидроконверсии, где ионизированная вода служит основным реагентом и насыщает непредельные углеводороды, образованные при разложении высокомолекулярных асфальтеносмолистых парафинов (АСП) на низкомолекулярные соединения моторных топлив [9-11], тем самым восполняет и небольшие газовые потери от колонного способа фракционирования.

Основываясь на технологии гидроконверсии нефтяного сырья, коллектив авторов сделал научное открытие [12]. Начало этому открытию положила научная статья автора [4], которая основывалась на инновационном патенте [13]. Затем была научная статья [14], расширяющаяся предмет [4]. Ссылаясь на [4, 13, 14], автор разработал Технические условия [15]. На базе инновационного патента [13] и Технических условиях [15] автором была построена пилотная технологическая линия по конверсии кислого гудрона на моторные топлива. На пилотной линии впервые удалось достичь глубину превращения кислого гудрона в сертифицированные по стандартам Евро-4 моторные топлива (автомобильные бензины Аи-91, Аи-95, Аи-98 и дизельное топливо) в 92\% на углеводородную массу сырья и еще на $12 \%$ массовых судового топлива, отвечающего требованиям Международной морской конвенции. Была установлена энергоэффективность (17кВт.час/тонна) процесса конверсии сверхтяжелых высокомолекулярных углеводородных соединений типа кислый гудрон в легкие светлые фракции [16].

На основе демонстрационных испытаний пилотной линии с участием экспертов центральной лаборатории Федерального агентства по техническому регулированию и метрологии (г. Москва) и, согласно их заключениям, был получен Сертификат соответствия Российской Федерации [17] и пакет разрешительных документов на серийное изготовление и промышленное применение входящих в линию технологических реакторов в условиях пожаровзрывоопасных предприятий. 
Первый минизавод вакуумно-волновой конверсии органических и неорганических соединений магнитоэлектрическим полем на нефтехимические продукты и моторные топлива построен и введен в эксплуатацию 2018 г. Его мощность составляет 50 тыс. т в год. Сырьем для минизавода служат нефтешлам и ПНБ. Ввод в эксплуатацию и испытания реакторов проводились на природном нефтебитуме месторождения «Жангурщи» полуострова «Бузачи» Мангистауской области. Заключение по результатам испытаний было сделано Международной аккредитованной лабораторией SGS-Kazakhstan. Результаты анализов опубликованы в [18]. Поразительны такие факты: кинематическая вязкость сырья, составляющая при $\mathrm{t}=+20^{\circ} \mathrm{C}$ величину $3628 \mathrm{cC}$, упала до величины $24 \mathrm{cC}$; температура конца кипения с $+658^{\circ} \mathrm{C}$ снизилась до $+423^{\circ} \mathrm{C}$; остаток после отгона светлых фракций, выкипающих до $+350^{\circ} \mathrm{C}$, представлял собой печное топливо с температурой застывания $-27^{\circ} \mathrm{C}$. Эти факты говорят о возможностях открытия [12] многократно увеличивать нефтяные запасы и поднять экспортный потенциал Казахстана, оцениваемые на сотни миллиардов долларов США [8].

Цель статьи заключается в исследовании возможных областей приложения технологии низкотемпературной вакуумно-волновой гидроконверсии (ВВГ) нефтяного сырья любой природы, с любым серосодержанием и гетероатомными соединениями, а также в демонстрации технической реализуемости и экономической эффективности ВВГ.

\section{ОБЛАСТЬ ПРИМЕНЕНИЯ И ЭКОНОМИЧЕСКИЙ ЭФФЕКТ}

Каждое месторождение нефти, нефтегаза и газоконденсата имеет Центр подготовки и перекачки нефти (ЦППН), где из промысловой сырой нефти производится товарная нефть, отвечающая требованиям международных стандартов, в частности ГОСТ Р 51858-2012 [3]. ЦППН-ы, во-первых, обессоливают, обезвоживают и очищают от механических примесей с употреблением большого количества пресной воды, во-вторых, производят дегазацию нефтей. Нормативные показатели этих технологических процессов задаются стандартами и вписываются в паспорт качества каждой партии нефти.

Наше предложение: сохраняя инфраструктурную часть ЦППН-ов, ввести в их состав Комплекс облагораживания углеводородов (КОУ), являющийся частью технологической линии вакуумно-волновой гидроконверсии (без колонны), для:

- Подъема потенциала УВС до 92\% и выше;

- Снижения температуры начала кипения до $+72^{\circ} \mathrm{C}$ и ниже, температуры конца кипения до $+420^{\circ} \mathrm{C}$ и ниже;

- Очистки от серы до 0,5\% и ниже и полную от меркаптановой серы;

- Полной очистки от гетероатомных соединений;

- Гидрогенизации конечного углеводородного топлива с использованием от 4\% до $40 \%$ ионизированной воды по массе.

Гидрогенизированное ( $40 \%$ ионизированной воды) топливо имеет товарную марку «Топливо гидрогенизированное энергетическое» (ТГЭ-40) [15]. Топливо, использующее для гидрогенизации порядка 4\% массовых ионизированной воды, будет именоваться «Топливо жидкое дистиллятное» (ТЖД) [15]. Кинематическая вязкость ТЖД при температуре $+20^{\circ} \mathrm{C}$ будет не более $6 \mathrm{cC}$, а плотность - не бо- 
лее 825 кг $/ \mathrm{M}^{3}$. Битуминозная нефть типа 4 по ГОСТ Р 51858-2012 с плотностью 943 кг/ $\mathrm{M}^{3}$ при температуре $\mathrm{t}=20^{\circ} \mathrm{C}$ характеризуется коэффициентом баррелизации $\mathrm{K}=6,67$, а выработанные из неё ТЖД уже имеет $\mathrm{K}_{д}=7,62$ баррелей на тонну.

Как следует из [3], нефти типа 3 и 4 не экспортируются, но их много добываются (около 17 млн т в год). К тому же они высокосернисты (более 2\% массы) [3]. Средняя нефть Казахстана, подлежащая экспорту, имеет большое содержание парафинов: от 12\% до 23\% для нефтей Кумкольских, Аралкумских, Узени, Жетибая и многих других месторождений [19]. У этих типов нефтей - высокая температура застывания $\left(+30^{\circ} \mathrm{C}\right.$ и выше) и высокая кинематическая вязкость. Поэтому ПАО «ТРАНСНЕФТЬ» РФ, принимая нефть Казахстана на перекачку, накладывает штраф 30 долларов США на каждую её тонну. Штраф налагается согласно требованиям качества по содержанию парафина, серы, солей и воды, температуре застывания, вязкости и плотности.

Итак, ТЖД отличается в лучшую сторону по коэффиценту баррелизации, низким содержанием парафина и серы, низкими значениями температуры застывания и вязкости. Главное, ТЖД имеет 92\% светлых фракций, следовательно, его котировка должна быть выше, чем у BRENT - международной эталонной нефти на Лондонской бирже (как минимум на 5 долларов США). Вместо штрафа на ТЖД полагается премия, ибо оно относится к категории премиальных нефтей. Для подтверждения изложенного приведем анализ нефтешлама CNPC-Aktobe и ТЖД, выработанного из него (таблица 1).

Таблица 1 - Характеристики нефртешлама CNPC-Aktobe и ТЖД, выработанного из него

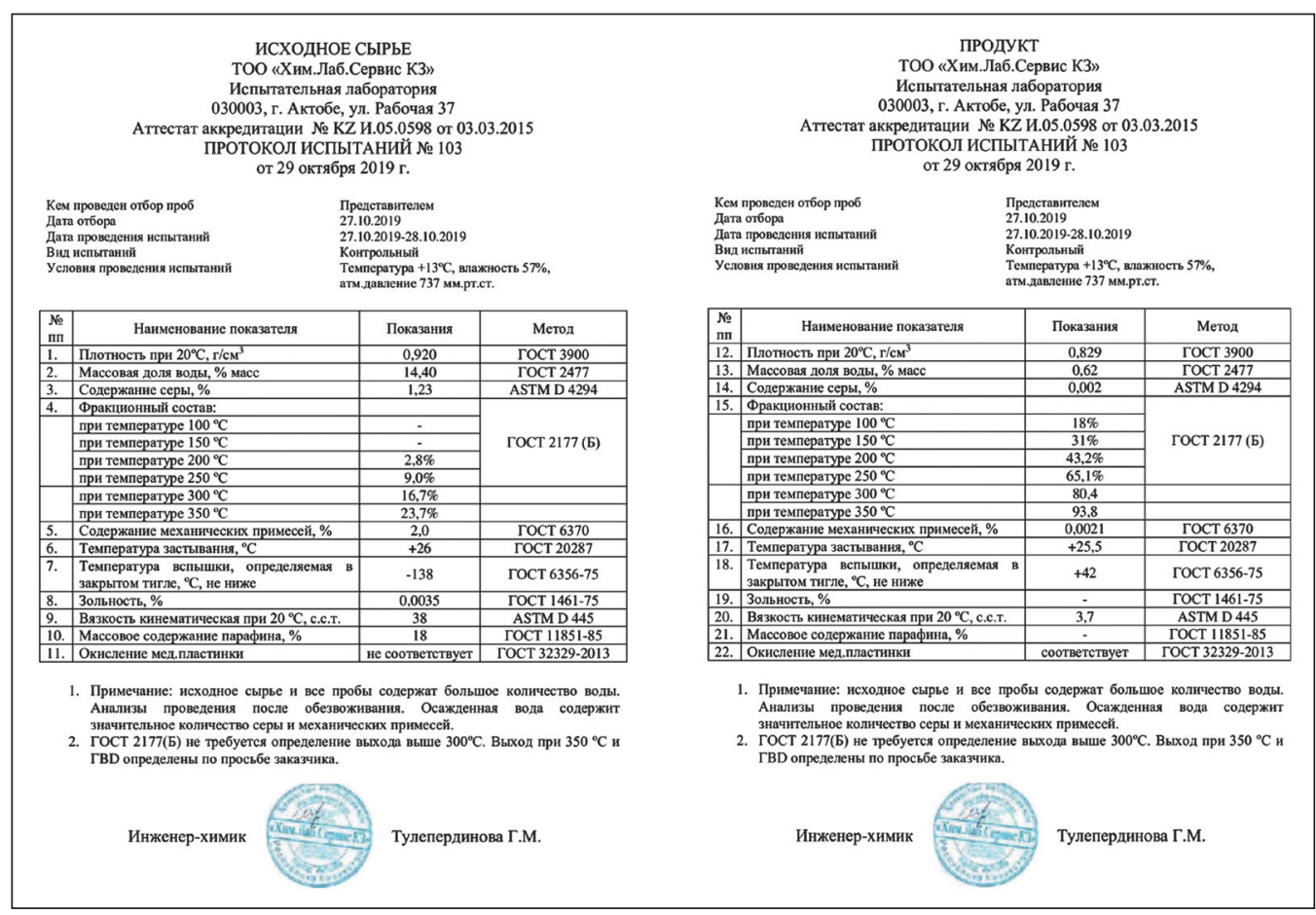


Как показывает таблица 1, данный нефтешлам представляет собой битуминозную нефть (тип 4), сернистую (1,23\%), высокопарафинистую (16\%), высокозастывающую $\left(+25^{\circ} \mathrm{C}\right)$, высоковязкую $(38 \mathrm{cC})$ и низкопотенциальную $\left(23,7 \%\right.$ до $\left.+350^{\circ} \mathrm{C}\right)$. Его ТЖД представляет товар по качеству значительно превосходящий BRENT и относящийся к категории премиальных нефтей.

Мы рекомендуем продавать не нефть, а выработанное из нее ТЖД. Это позволит поднять доходность нефтяной отрасли. Ссылаясь на итоги 2018 г., министр энергетики К. Бозумбаев сообщил, что добыча нефти впервые в истории страны достигла объема 90360 тысяч тонн [20]. По его словам, это стало возможным благодаря росту добычи на новом месторождении «КАШАГАН» - на шельфе Каспийского моря. Из указанного объема нефти не более 7,3 млн тонн перевозятся на танкерах и цистернах (ж/д транспорт). Следовательно, на долю АО «Казтрансойл» приходится транспортировка около 83 млн тонн нефти, из которых до 37 млн транспортируемого объема Казтрансойл передает ПАО «Транснефть» РФ. Казахстан платит за массу (тоннаж) транспортируемой нефти: рост объема транспортируемой нефти, связанной со снижением ее плотности, никак не сказывается на наших оплатах ПАО «Транснефть». Учитывая, что конечный потребитель нефти рассчитывается с Казахстаном по биржевой цене за баррель нефти, можем заключить, что минимальный прирост коэффициента баррелизации на 0,4 единиц дает дополнительный доход

$$
37 * 106 * 0,4 * 71,9=1164,120 \text { млн USD }
$$

Кроме того, за указанный объем нефти Казахстан не платит штраф, так как качество нашей нефти, согласно таблице 1 , удовлетворяет все требования ПАО «Транснефть». Тогда штрафная сумма идет в доход Казахстана:

$$
37 * 106 * 30=111,000 \text { млн USD }
$$

Как известно, при транспортировании высокозастывающей нефти из-за парафинов (таблица 1) ее постоянно подогревают, пропуская весь объем через станции попутного подогрева. При этом котельным топливом служит сама нефть и $10 \%$ транспортируемого объема расходуется на подогрев магистрального нефтепровода. Для ТЖД подогрев не нужен, причем его кинематическая вязкость позволяет увеличить объем прокачиваемой нефти на $40 \%$ и более по той же трубе. Сказанное эквивалентно тому, что 3,7 млн тонн нефти, ранее используемой в качестве котельного топлива, становится товарной нефтью для экспорта и дает дополнительный доход:

$$
3,7 * 106 * 7,65 * 72=2037,960 \text { млн USD }
$$

Складывая (1) - (3), получим доход, представляющий собой издержки процесса подготовки товарной нефти в ЦППН-ах и транспортировки товарной нефти до потребителя по транспортной нефтяной трубе. Объем этого дохода равняется:

$$
\mathrm{Q}=(1064,120+1 \text { 110,000 + } 2 \text { 037,960) млн. }=4212,080 \text { млн. USD }
$$

Таких же результатов можно достичь, устраняя издержки перевозки товарной нефти на танкерах и цистернах. Следовательно, можем утверждать, что внедрение технологии низкотемпературной вакуумно-волновой гидроконверсии в процессах подготовки и производства товарной нефти, соответствующей по качественным показателям ТЖД, и перекачки ее по трубопроводно-транспортной системе и наземному транспорту, может добавить не менее 4,2 млрд долларов США дохода в экономику отрасли. При этом не меняются инфраструктура и сами процессы, только вписы- 
вается технологическая линия КОУ в существующую инфраструктуру, упрощает технологический процесс, повышающий его энергоэффективность и экологичность.

В связи с этим рассмотрим принципиальную технологическую схему (рисунок 1), применяемую в развитых странах (США, Евросоюз, Япония и Китай) и обеспечивающую выход 92\% массовых моторных топлив, вторичных топлив типа судовых и печных, а также дорожного битума и нефтяного кокса [21,22]:

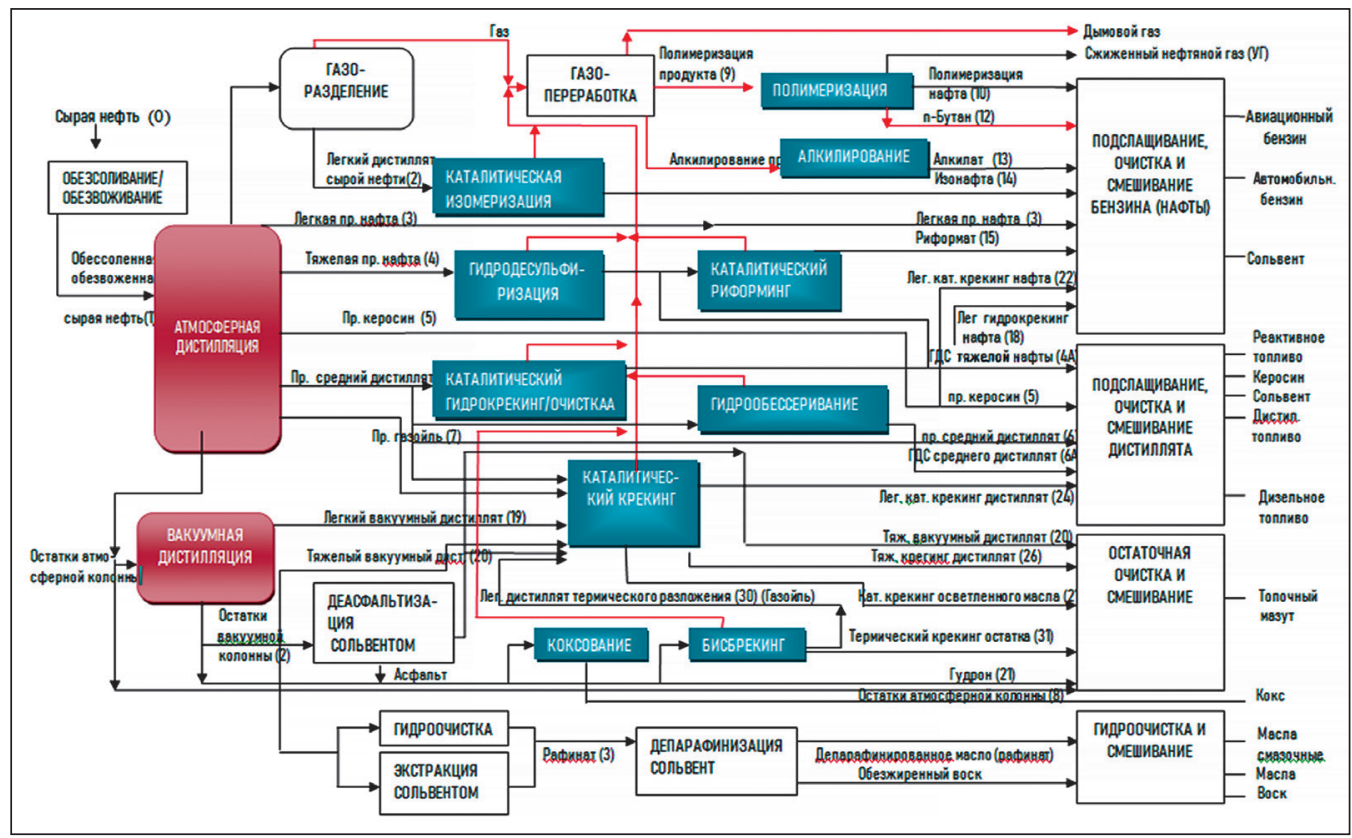

Рисунок 1 - Принципиальная технологическая схема глубокой переработки товарной средней нефти типа 2

Для сравнения рассмотрим разработанный нами процесс сверхглубокой переработки нефти с достижением рекордного объема выхода моторных топлив (не менее 92\% массовых) и 12\% судового топлива на нефть любого качества. Отметим управляемость процесса гидроконверсии и возможность сохранения потенциала $(92 \%)$ при обеспечении температуры начала кипения ТЖД от $+72^{\circ} \mathrm{C}$ и выше. Тогда не будет выделяться газ, отсутствует легкий бензин, именуемый газовой головкой, и все $92 \%$ состоят из фракции автомобильного бензина, авиакеросина и дизельного топлива. При этом процесс полноценного фракционирования обеспечивается одной атмосферной колонной.

Технологическую схему глубокой переработки, указанной на рисунке 1, У. Леффлер [21] называет особо сложныым процессом. По его данным, на блоке ЭЛОУ-АВТ для средних нефтей типа 2 [3] получается:

- Выделение газов до 0,1\% массовых;

- Сухой газ стабилизации бензина до $0,2 \%$ масс;

- Сжиженная головка стабилизации бензина, включающая примесь пентанов, до 0,3\% масс;

- Легкая головка бензина (от температуры начала кипения до $85^{\circ} \mathrm{C}$ ) до $6 \%$ на нефть; 
- Бензиновая фракция до 14\% масс;

- Керосиновая фракция до 16\% масс;

- Дизельная фракция до $18 \%$ масс;

- Вакуумный газойль $\left(350^{\circ} \mathrm{C} \div 500^{\circ} \mathrm{C}\right)$ до $20 \%$ масс;

- Тяжелый мазут вакуумный до $25 \%$ масс.

Итого, на этом блоке выход фракции моторных топлив составляет не более $48 \%$ от потенциала нефти в 54\% массовых и более. Для увеличения выхода фракций моторных топлив гидроочищенный вакуумный газойль (ВГО) подвергают каталитическому крекингу и дополнительно извлекают до $15 \%$ массовых фракций бензина и дизельного топлива. Гидроочищенный вакуумный мазут, разбавленный с ВГО, перегоняют в атмосфере водорода (до 4\% масс) в колоннах гидрокрекинга и извлекают дополнительно до $10 \%$ дизельного топлива. Общие мазутные остатки после гидроочистки направляют в установку замедленного коксования (УЗК), которая дает высококачественный нефтяной кокс, и/или в битумную установку для производства дорожно-строительного и строительного битума. При этом УЗК может дать небольшое количество (до 4\% массу мазута) бензин УЗК (темный продукт), который добавляется в гудрон (температура кипения выше $+500^{\circ} \mathrm{C}$ ) для выработки котельного топлива.

Используя упомянутую технологическую схему, нефтеперерабатывающие отрасли (НПО) США, Японии и Китая добились выхода 73\% массовых моторных продуктов и 19\% вторичных нефтепродуктов с достаточно высокой добавленной стоимостью, в целом доводящих глубину переработки до 92\% с технологическими потерями в 5-8\%. Следует подчеркнуть, что указанные потери имеют место несмотря на их восполнение при гидроочистках прямогонного мазута атмосферных колонн в атмосфере водородосодержащих газов (ВСГ), составляющих до 6\% массовых, и далее используемых гидроочистных процессов ВГО, продуктов каталитического крекинга и гидрокрекинга с использованием ВСГ и водорода, масса которых доходит до $20 \%$. Основную долю потери составляют коксовые отложения в колоннах и их катализаторах, имеющие общую массу до 6-8\%. Из-за этих отложений, НПЗ останавливают два раза в году на плановое техническое обслуживание, имеющее общую продолжительность в 760 часов.

Профессор У. Леффлер [21] не считает затраты в нефтяном эквиваленте и не учитывает массу вовлекаемых в моторные топлива присадок и добавок, составляющую 5\% от массы топлив и повышающую их товарные качества. Более полный массоэнергетический баланс в нефтяном эквиваленте проделан [22] и показан, что он составляет $22-25 \%$ от углеводородной массы исходного сырья. Следовательно, глубину переработки в $92 \%$ и выход моторных топлив в $73 \%$ массовых нужно считать от $78 \%$ (75\%) углеродной массы сырья в нефтяном эквиваленте. Тогда истинная глубина переработки средней нефти и конечный выход моторных топлив будут составлять не более $72 \%$ (69\%) и $57 \%$ (55\%) соответственно. При тех же условиях технология вакуумно-волновой гидроконверсии углеводородного сырья независимо от его качества обеспечивает выход моторных топлив в 92\% массовых против 57\% (55\%) и еще $12 \%$ массовых судовых топлив, составляющих глубину переработки в 104\% массовых по сравнению с имеющимися достижениями современной НПО в $72 \%$ (69\%). 


\section{НЕФТЕХИМИЯ}

Учитывая эти факты, можно заключить, что научное открытие [12], внедренное в НПО для глубокой переработки товарных нефтей, во-первых, снижает эксплуатационные затраты (ОРЕХ), во-вторых, дает дополнительную продукцию $(92-57=35 \%)$, составляющую 35\% массы перерабатываемого сырья. Такое производство имеет принципиальную технологическую схему (рисунок 2), где вместо цеха подготовки нефти к переработке стоит КОУ. Для КОУ сырьем служат все типы традиционных нефтей, нетрадиционная нефть (см. выше), темные вторичные нефтепродукты (ВГО, мазут, гудрон) и промышленные нефтяные отходы (кислые гудроны, нефте-

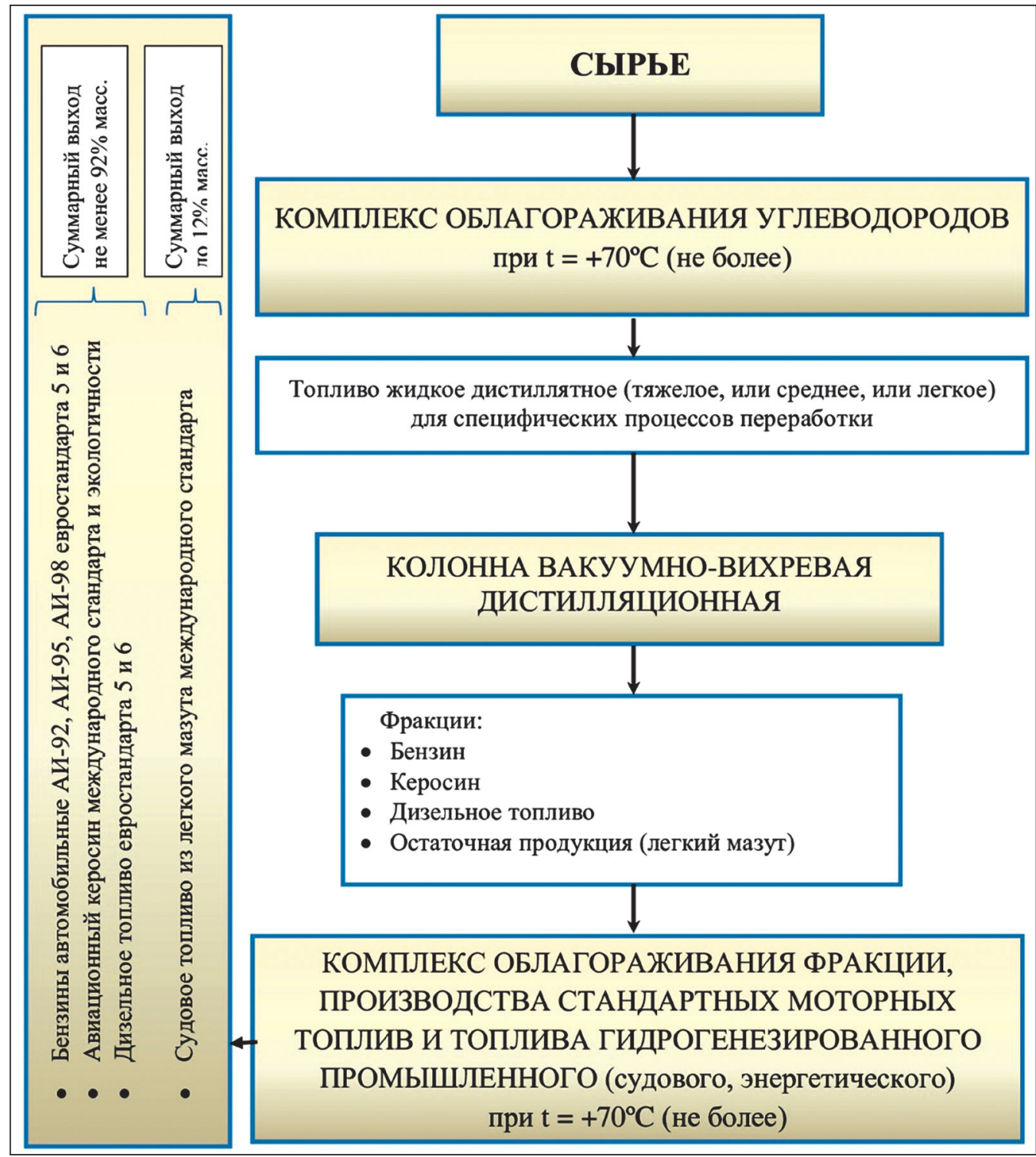

Рисунок 2 - Принципиальная схема вакуумно-волновой гидроконверсии нефтяного сырья на моторные топлива 
шламы). КОУ из сырья выпускает ТЖД с потенциалом 92\% масс и более, которое подогревается до $+300^{\circ} \mathrm{C}$, подается в атмосферную колонну и фракционируется на фракции бензина, авиакеросина и дизельного топлива.

Разница по производству товарной продукции (моторные топлива), согласно показанным схемам (рисунки 1 и 2), составляет как минимум 35\% или 350 кг на каждую тонну сырья и представляет собой в основном дизельное топливо. Для расчета берем общую производительность трех основных НПЗ Казахстана - 17,2 млн тонн в год. Применительно к этому объему внедрение открытия [12] позволило бы иметь дополнительно порядка 6 млн тонн в год дизельного топлива. Из этого объема 3,5 млн тонн следует считать летним топливом с оптовой ценой 185 тыс. KZT за тонну и 2,5 млн тонн - это зимнее дизельное топливо с оптовой ценой 275 тыс. KZT за тонну или общий доход будет составлять 3,12 млрд USD в год (1USD в 428 KZT).

Сравнивая технологические схемы, изображенные на рисунках 1 и 2, замечаем, что схема 2 дешевле первой как по удельным капитальным затратам (KAPEX), так и по операционным затратам (OPEX). Оценки даны в статьях [9-11]. Очень важный фактор, изученный и оцененный профессором А.К. Мановяном [22], заключается в том, что повышение глубины переработки нефти на 1\% массовых по затратам в среднем ниже в 14-20 раз затрат, израсходованных на увеличение коэффициента извлечения нефти из недр на 1\% массовых. Эффективность ВВГ ни у кого не вызывает сомнений. Более того, переработка нефти значительно дешевле передела ВГО и мазута. Типовые НПЗ с гидроочисткой сырья и продуктов, каталитическим крекингом и риформингом топлив имеют мощность 6 млн тонн в год. Аналогичные НПЗ, имеющие еще гидрокрекинг и установки производства и очистки водорода, имеют типовую мощность в 10 млн тонн в год. Установленные мощности (10 млн т/год) указанных типов НПЗ связаны со сроком окупаемости: ниже указанных мощностей срок окупаемости увеличивается, выше - сокращается. Поэтому в мире принята новая тенденция об увеличении мощности единичных НПЗ на несколько десятков миллион тонн в год. К примеру, первый в мире 30-миллионный НПЗ построен и введен в эксплуатацию в Венесуэле, строится НПЗ с мощностью 32 млн тонн в год в Индии. У этих НПЗ расчетный срок окупаемости не более 5 лет, т. е. ниже, чем у традиционных 10-миллионных НПЗ. Внедрение открытия [12] и строительство НПЗ любой мощности, спаренной с КОУ, обеспечивает глубину переработки 92\% по топливному варианту и окупается в срок не более 2-2,3 года. При этом нет необходимости выбирать нефть по качеству, ибо КОУ способен перерабатывать УВС любого качества в ТЖД с заданным фракционным составом [9-11].

Действующий КОУ на 100 тысяч тонн изображен на рисунке 3, его инфраструктура - на рисунке 4 и колонна - на рисунке 5. Инфраструктура построена так, чтобы мощность КОУ можно было поднять от 1 до 6 млн тонн/год, т. е. мини НПЗ постепенно можно преобразовывать в полноценный НПЗ. При этом КАРЕХ НПЗ, работающий по схеме (рисунок 1), снижается с 780 USD/т до 187 USD/т (рисунок 2) или на 400 долларов США. Тогда KAPEX 6-миллионной НПЗ составляет 1.120,0 млн USD вместо общемировых 4.680,0 млн USD, т. е. в 4 раза. Аналогично, ОРЕХ НПЗ снижается со 183 USD/т до 25USD/т, или в 7 раз. Это без учета стоимости добавок и присадок к продуктам и сырью. 


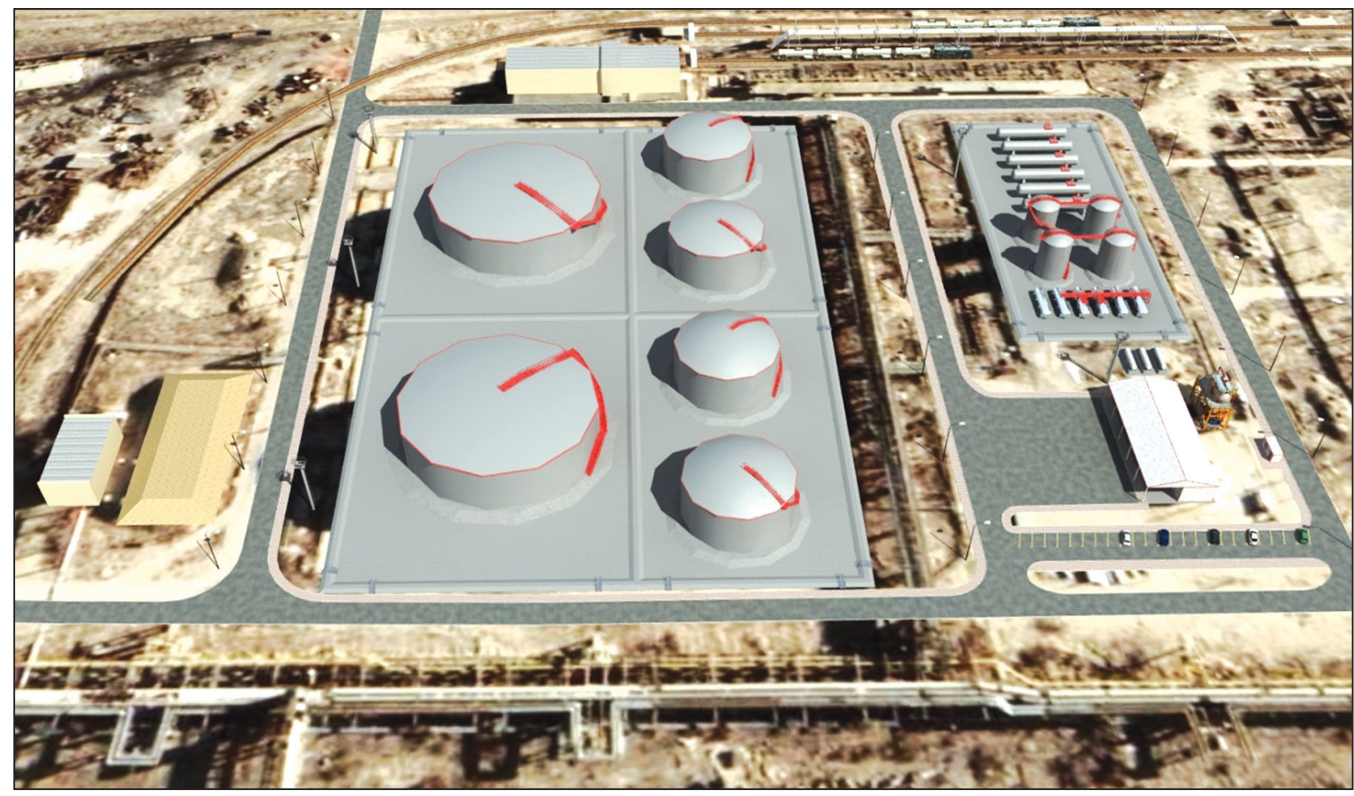

Рисунок 3 - Действующий КОУ, мощностью 100 тысяч тонн

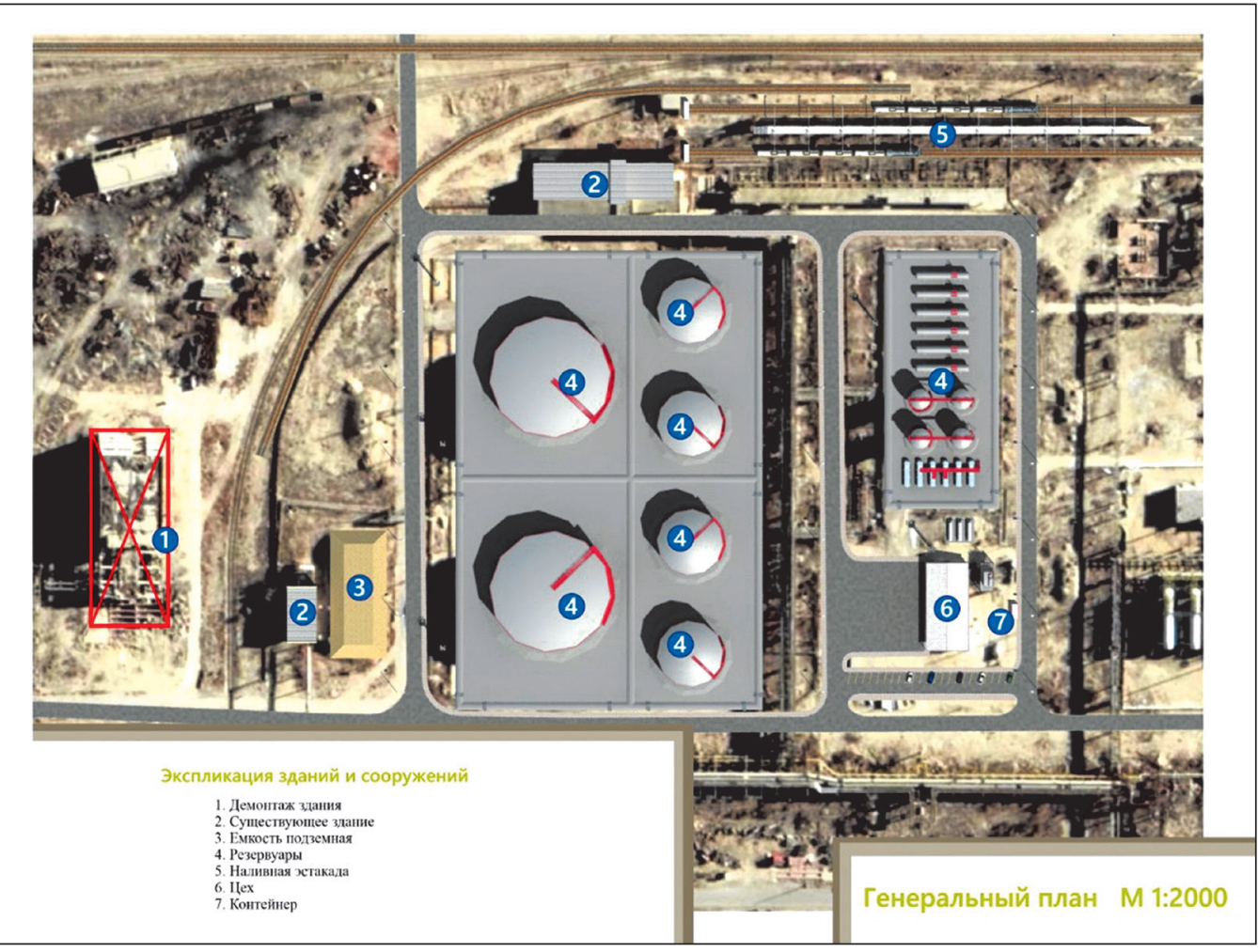

Рисунок 4 - Инфраструктура КОУ 


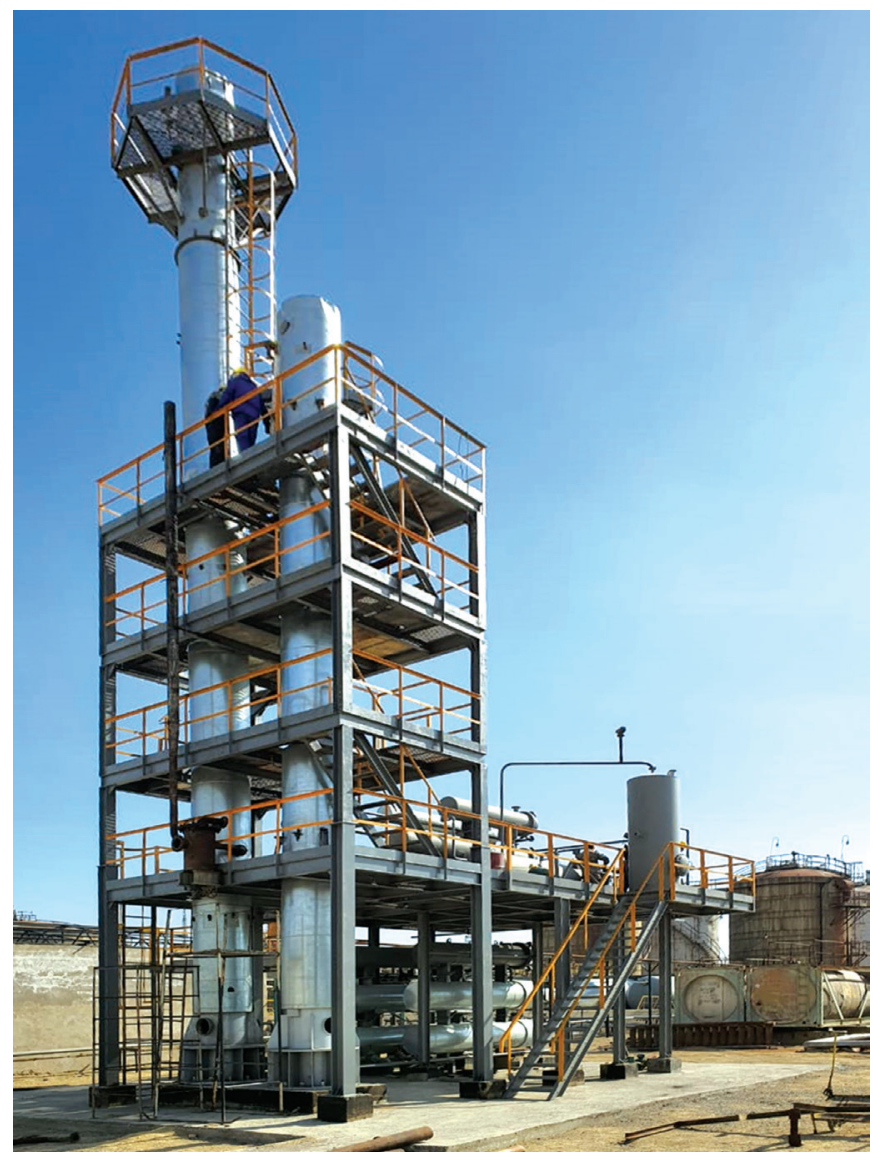

Рисунок 5 - Колонна

Заключение 1. По мере истощения запасов легких, среднелегких и средних нефтей, проблема их подготовки к транспортировке и переработке с минимальными энергозатратами обретает все более важное значение. В традиционном смысле под подготовкой нефти понимают ее глубокие дегазацию, обессоливание и обезвоживание [22]. Этот процесс не меняет природные химический и фракционный составы нефтяного сырья. Учитывая, что подготовка нефти осуществляется сначала на промыслах (ЦПНН-ы), затем на НПЗ в цехах подготовки сырья к переработке, нами рекомендуется поставить: Комплексы облагораживания углеводородов (КОУ), способные при температуре не выше $+70^{\circ} \mathrm{C}$ изменять химический и фракционный составы так, чтобы задать термокрекинговый режим с фиксированными температурами начала $\left(+72^{\circ} \mathrm{C}\right.$ и выше) и конца кипений $\left(+430^{\circ} \mathrm{C}\right)$, измененными реологическими свойствами, обеспечивающие заданные температуру застывания, кинематическую вязкость и фильтруемость. При этом под изменением химического состава понимается снижение содержания серы до $0,02 \%$ массовых и ниже, оксидантов до полного исчезновения, металлов, минералов, солей до нуля. Указанный процесс нами назван облагораживанием УВС, и он резко отличается от традиционных, высокотемпературных, каталитических процессов облагораживания [21,22]. 
Заключение 2. КОУ выдает ТЖД, подлежащее к фракционированию и производству фракции автомобильного бензина, авиакеросина, дизельного топлива, составляющих не ниже 92\% массовых на сырье, и остаточного нефтепродукта, которое КОУ может превратить в судовое или легкое котельное топливо. Мы рекомендуем для фракционирования ТЖД на фракции моторных топлив специальную колонну, снабженную волновыми генераторами, обеспечивающими снижение температуры фракционирования ТЖД на моторные топлива до $+270^{\circ} \mathrm{C}$ за счет тепловых воздействий электромагнитных волн [24].

Заключение 3. Полученные фракции моторных топлив нуждаются в процессах их превращения в товарные автомобильные бензины Международного стандарта Евро 5 и 6, дизельное топливо марки «Летнее», «Межсезонное» и «Зимнее» по стандарту Евро 5 и 6. Авиакеросин делится на авиационное топливо для дозвуковых самолетов и для звуковых и сверхзвуковых летательных аппаратов, соответственно отличающихся по узкофракционному составу и содержанию ароматических соединений.

На типовых НПЗ эти требования обеспечиваются колоннами вторичной перегонки бензиновой и дизельной фракций, колоннами каталитического риформинга, смесителями фракции с различными присадками, добавками, обеспечивающими нужные октановые и цетановые числа, цетановый индекс, температурные показатели и реологические свойства.

Эти дорогостоящие процессинговые операции заменяет и более эффективно и дешево реализует Комплекс облагораживания углеводородов-2 (КОУ-2). Данный Комплекс состоит из тех же реакторов, что и КОУ, снабженных дополнительными волновыми генераторами, обеспечивающими в три раза низкое употребление присадок и добавок к топливам, длительный срок хранения и стойкость показателей бензина, керосина и дизельных топлив, а также повышение теплоты и полноты их сгорания как минимум на $30 \%$.

Заключение 4. Мировая экономика потребляет ежедневно не менее 84 млн баррелей нефтей в пересчете на среднюю нефть (тип 2 ГОСТ Р 51858-2012), намечается их прирост до 110 млн баррелей в ближайшие 10 лет [3]. Иначе говоря, годовое потребление нефти с нынешних 4,2 млрд тонн подрастет до 5,5 млрд тонн, т. е. прирост составляет 23,6\% к 2030 году. Не трудно заметить, что широкомасштабность использования технологии ВВГ в производстве товарной нефти из сырой нефти, ее транспортировке и переработке по варианту моторного топлива позволяет сохранить нынешний объем ее добычи (4,2 млрд тонн/год) и дает возможность значительно снизить углеродное содержание мирового ВВП, успешно справиться с достижением нужного показателя выброса парниковых газов без дополнительных мер борьбы с климатическими изменениями.

По данным Международного энергетического агентства [2], около 42\% энергетики приходится на долю нефтяного котельного топлива. Это - порядка 1,2 млрд тонн мазута марки 100. Если от мазута перейти к ТГЭ-40, то объем потребления мазута снижается в 1,67 раза и становится равным 485 млн тонн. Тогда доля перерабатываемого по топливному варианту углеводородного энергоносителя возрастет на 715 млн тонн ежегодно, что способствует снижению потребности в нефтях всей 
мировой экономики. Тем самым ВВГ дает дополнительный источник снижения углерода в экономике и выбросов ПГ в климатических изменениях.

Заключение 5. ТЖД является уникальным растворителем тяжелых, твердых парафинов и асфальтеносмолистых соединений, объединяемых под общим названием «Асфальтеносмолистые парафины» АСП. При этом один объем ТЖД растворяет не менее 4-х объемов тяжелых парафинов и не менее 6-и объемов АСП до продукта, близкого по химическому и фракционному составам к ТЖД. Поэтому нами была проведена серия опытных испытаний ТЖД по очистке нефтяных резервуаров от 2000 м $^{3}$ до 20000 м $^{3}$ с отложениями в донных частях и на стенках, составляющими до $12 \%$ от объема очищаемого резервуара. На примере резервуара с вместимостью $20000 \mathrm{M}^{3}$, отложения составляют $2400 \mathrm{M}^{3}$, основная часть которых приходится на данные остатки. В резервуар с нижнего его сливного патрубка нагнетаем (P 0,5MПа) ТЖД в объеме $600 \mathrm{~m}^{3}$. После этого отложения в резервуаре стоят 40 минут, за которое ТЖД разжижает их до текучего состояния. Отсоединяем насос и прикрепляем его всасывающую линию на нижний патрубок, а нагнетательную линию - на верхний сливной патрубок резервуара и в течение 3-х часов насос работает в режиме рецикла: берет с нижнего патрубка, нагнетает через верхний патрубок, пропуская отложения через реакторы К-21 и К-34. Такой цикл позволяет превратить отложения в растворитель - ТЖД тяжелое, которое далее можно нагнетать в следующий резервуар, подлежащий к очистке от отложений.

Такой простой и эффективный способ очистки резервуаров от отложений будет востребован во всех отраслях нефтяной промышленности. Ясно, что данный способ может использоваться и в очистке от отложений нагнетательно-компрессорных и добычных труб, особенно от отложений парафинов, без их разбора и подъема на поверхность. Это многократно снижает затраты и время на подобную операцию.

Заключение 6. По данным МЭА [3], одна треть всего объема поставки товарных нефтей приходится на долю битуминозных нефтей (тип 4), природного нефтебитума и сланцевых нефтей. Себестоимость добычи ПНБ и сланцевой нефти более чем в 2 раза превышает аналогичную стоимость битуминозной нефти, которая в свою очередь $1,2 \div 1,5$ раза выше себестоимости добычи средней нефти. Переработка ПНБ и сланцевой нефти также дороже. Кроме того, в мире объем отработанных масел и неперерабатываемых отходов существующих НПЗ составляет сотни миллионов тонн в год. ВВГ позволяет освоить эти категории энергоносителей и может снизить объем нефтепотребления в целом.

Заключение 7. Очень важный момент - это многократное снижение как удельных капитальных затрат, так и удельных операционных затрат НПО. Материалоемкость НП3, особенно металлоемкость уменьшается в десятки раз. Повышается экологичность процесса сверхглубокой переработки нефти при сниженных энергозатратах с меньшей дозой всевозможных добавок и присадок, улучшающих качество продуктов. Все это позволяет заключить об исключительном месте и значимости технологии низкотемпературной вакуумно-волновой гидроконверсии УВС на моторные топлива и нефтехимические продукты с рекордным выходом целевых товаров. 
Заключая статью, автор выражает свою искреннюю благодарность академику Надиру Каримовичу Надирову - основателю и лидеру Казахстанской школы нефтехимии за помощь и настоятельные рекомендаџии по написанию данной работы и надеется, что она будет продолжена и дополнена другими авторами открытия [12].

\section{ЛИТЕРАТУРА}

1 Экологический кодекс Республики Казахстан https:/www.gov.kz/memleket/entities/ ecogeo?lang=ru [Ekologicheskij kodeks Respubliki Kazahstan]

2 Модель мировой экономики на период развития 2001-2030 годы. https://www.iea. org/ [Model' mirovoj ekonomiki na period razvitiya 2001-2030 gody]

3 ГОСТ Р 51858 -2012 «НЕФТЬ. Технические условия» - М.: ВНИПИ нефрть, 2012. 8 c. [GOST R 51858 -2012 «NEFT'. Tekhnicheskie usloviya» - M.: VNIPI neft', 2012. - 8 s.]

4 Калыбаев А.А. Теория и практика холодного крекинга // Вестник ИА РК. - 2003. №1(9). - C. 78-81. [Kalybaev A.A. Teoriya i praktika holodnogo krekinga // Vestnik IA RK. - 2003. - №1(9). - S. 78-81.]

5 Калыбай А.А. Энергоэффрективная сверхглубокая гидроконверсия высоковязких углеводородов в моторные топлива // Нефть и газ. - 2014. - №1. - С. 45-59. [Kalybaj A.A. Energoeffektivnaya sverhglubokaya gidrokonversiya vysokovyazkih uglevodorodov v motornye topliva // Neft' i gaz. - 2014. - №1. - S. 45-59.]

6 Калыбаев А.А., Надиров Н.К. Результаты гидродинамических исследований Кумкольских нефтей // Нефть и газ. - 2003. - №4. - С. 63-68. [Kalybaev A.A., Nadirov N.K. Rezul'taty gidrodinamicheskih issledovanij Kumkol'skih neftej // Neft' i gaz. - 2003. - №4. - S. 63-68.]

7 Калыбай А.А., Надиров Н.К. Новые фризико-химические принципы глубокой переработки высоковязких нефтей // Нефрть и газ. - 2008. - №3. - С. 34-44. [Kalybaj А.А., Nadirov N.K. Novye fiziko-himicheskie principy glubokoj pererabotki vysokovyazkih neftej // Neft' i gaz. - 2008. - №3. - S. 34-44.]

8 Надиров Н.К. Как сделать Казахстан самой конкурентоспособной и передовой нефртяной страной мира // Нефть и газ. - 2020. - №3-4. - C. 7-50. [Nadirov N.K. Kak sdelat' Kazahstan samoj konkurentosposobnoj i peredovoj neftyanoj stranoj mira // Neft' i gaz. - 2020. - №3-4. - S. 7-50.]

9 Калыбай А.А., Жумагулов Б.Т., Надиров Н.К., Абжали А.К. Альтернативная технология эфффективной переработки нефтяного сырья // Нефть и газ. - 2007. - №3. - С. 88-104. [Kalybaj A.A., Zhumagulov B.T., Nadirov N.K., Abzhali A.K. Al'ternativnaya tekhnologiya effektivnoj pererabotki neftyanogo syr'ya // Neft' i gaz. - 2007. - №3. - S. 88-104.]

10 Калыбай А.А., Жумагулов Б.Т., Надиров Н.К., Абжали А.К. Обоснование целесообразности строительства четвертого НПЗ с учетом эфффективной технологии переработки тяжелого нефтяного сырья // Нефть и газ. - 2018. - №4. - С. 67-77. [Kalybaj A.А., ZHumagulov B.T., Nadirov N.K., Abzhali A.K. Obosnovanie celesoobraznosti stroitel'stva chetvertogo NPZ s uchetom effektivnoj tekhnologii pererabotki tyazhelogo neftyanogo syr'ya // Neft' i gaz. - 2018. - №4. - S. 67-77.]

11 Надиров Н.К., Калыбаев А.А., Нуржанова С.Б., Хайрулина Р.Б. Влияние комплекса электромагнитных полей на свойства высоковязких нефтей // Нефть и газ. - 2004. №1. - C. 89-103. [Nadirov N.K., Kalybaev A.A., Nurzhanova S.B., Hajulina R.B. Vliyanie kompleksa elektromagnitnyh polej na svojstva vysokovyazkih neftej // Neft' i gaz. - 2004. - №1. - S. 89-103.] 
12 Жумагулов Б.Т., Калыбай А.А., Надиров Н.К., Абжалиев А.К. Научное открытие «Явление низкотемпературной вакуумно-волновой гидроконверсии нефтяного сырья». Москва. Диплом № 513. Международная академия авторов научных открытий и изобретений, Заявка на открытие и экспертиза №A-665 от 30.04.2019 г. [Zhumagulov B.T., Kalybaj A.A., Nadirov N.K., Abzhaliev A.K. Nauchnoe otkrytie «YAvlenie nizkotemperaturnoj vakuumno-volnovoj gidrokonversii neftyanogo syr'ya». Moskva. Diplom № 513. Mezhdunarodnaya akademiya avtorov nauchnyh otkrytij i izobretenij, Zayavka na otkrytie i ekspertiza №A-665 ot 30.04.2019 g.]

13 Инновационный патент № 11314 РК. Способ конверсии углеводородного сырья / Калыбаев А.А., Аспандияров Б.Б. От 2000 г. [Innovacionnyj patent № 11314 RK. Sposob konversii uglevodorodnogo syr'ya / Kalybaev A.A., Aspandiyarov B.B. Ot 2000 g.]

14 Калыбай А.А. Энергоэффективная сверхглубокая гидроконвверсия высоковязких углеводородов в моторные топлива // Нефть и газ. - 2014. - №1. - C. 45-59. [Kalybaj A.A. Energoeffektivnaya sverhglubokaya gidrokonvversiya vysokovyazkih uglevodorodov v motornye topliva // Neft' i gaz. - 2014. - №1. - S. 45-59.]

15 Технические условия ТУ 3689-001-38281705-2012 «Технологическая линия вакуумно-волновой конверсии углеводородного сырья магнитно-электрическим полем в топливо легкое, среднее и тяжелое дистиллятное жидкое (топливо жидкое: для специфических процессов переработки), бензины АИ-92, АИ-95, АИ-98 Евроклассов 4 и 5, дизельное топливо Евроклассов 4 и 5, топливо судовое и топливо гидрогеннизированное энергетической марки ТГЭ-40. - М.: ФБУ «РОСТЕСТ - МОСКВА», 2012. -26 c. [Tekhnicheskie usloviya TU 3689-001-38281705-2012 «Tekhnologicheskaya liniya vakuumno-volnovoj konversii uglevodorodnogo syr'ya magnitno-elektricheskim polem $v$ toplivo legkoe, srednee i tyazheloe distillyatnoe zhidkoe (toplivo zhidkoe: dlya specificheskih processov pererabotki), benziny Al-92, Al-95, Al-98 Evroklassov 4 i 5, dizel'noe toplivo Evroklassov 4 i 5, toplivo sudovoe i toplivo gidrogennizirovannoe energeticheskoj marki TGE-40. - M.: FBU «ROSTEST - MOSKVA», 2012. -26 s.]

16 Калыбай А.А., Надиров Н.К. Проблемы экологического мониторинга и создания наблюдательной сети // Доклады седьмых Международных научных Надировских чтений. - Алматы - Уральск, 2009. - С. 507-512. [Kalybaj A.A., Nadirov N.K. Problemy ekologicheskogo monitoringa i sozdaniya nablyudatel'noj seti // Doklady sed'myh Mezhdunarodnyh nauchnyh Nadirovskih chtenij. - Almaty - Ural'sk, 2009. - S. 507-512]

17 Российская Федерация. Сертификат соответствия № C-RU. AГ98. B. 09607 - TP 1457858 подтверждает, что Оборудование нефтеперерабатывающее: технологическая линия вакуумно-волновой конверсии углеводородного сырья магнитоэлектрическим полем и соответствует Технические условия ТУ 3689-001-38281705-2012 «Технологическая линия вакуумно-волновой конверсии углеводородного сырья магнитно-электрическим полем в топливо легкое, среднее и тяжелое дистиллятное жидкое (топливо жидкое: для специфических процессов переработки), бензины АИ-92, АИ-95, АИ-98 Евроклассов 4 и 5, дизельное топливо Евроклассов 4 и 5, топливо судовое и топливо гидрогеннизированное энергетической марки ТГЭ-40. - М.: ФБУ «РОСТЕСТ - МОСКВА», 2012. -26 c. [Rossijskaya Federaciya. Sertifikat sootvetstviya № C-RU. AG98. V. 09607 - TR 1457858 podtverzhdaet, chto Oborudovanie neftepererabatyvayushchee: tekhnologicheskaya liniya vakuumno-volnovoj konversii uglevodorodnogo syr'ya magnitoelektricheskim polem i sootvetstvuet Tekhnicheskie usloviya TU 3689-001-38281705-2012 «Tekhnologicheskaya liniya vakuumno-volnovoj konversii uglevodorodnogo syr'ya magnitno-elektricheskim polem $v$ toplivo legkoe, srednee i tyazheloe distillyatnoe zhidkoe (toplivo zhidkoe: dlya specificheskih processov pererabotki), benziny Al-92, Al-95, Al-98 Evroklassov 4 i 5, dizel'noe toplivo Evroklassov 4 i 5, toplivo sudovoe i toplivo gidrogennizirovannoe energeticheskoj marki TGE-40. - M.: FBU «ROSTEST - MOSKVA», 2012. -26 s.] 
18 Калыбай А.А., Надиров Н.К., Бодыков Д.У., Абжали А.К. Высоковязкие нефти, природные битумы, нефтяные остатки и переработка их вакуумно-волновой гидроконверсией // Нефтьь и газ. - 2019. - №2. - C. 100-119. [Kalybaj A.A., Nadirov N.K., Bodykov D.U., Abzhali A.K. Vysokovyazkie nefti, prirodnye bitumy, neftyanye ostatki i pererabotka ih vakuumno-volnovoj gidrokonversiej // Neft' i gaz. - 2019. - №2. - S. 100-119.]

19 Надиров Н.К. Высоковязкие нефти и природные битумы. В 5 томах. Т.1. - Алматы: Ғылым, 2001. - 360 с. [Nadirov N.K. Vysokovyazkie nefti i prirodnye bitumy. V 5 tomah. T.1. - Almaty: Fylym, 2001. - 360 s.]

20 Надиров Н.К. Высоковязкие нефти и природные битумы. В 5 томах. Т.5. - Алматы: Ғылым, 2001. - 337 с. [Nadirov N.K. Vysokovyazkie nefti i prirodnye bitumy. V 5 tomah. T.5. - Almaty: Fylym, 2001. - 337 s.]

21 Итоги работы Министерства энергетики за 2018 год и задачи на 2019 год II // Нефть и Газ. - 2019. - №2. - С. 153. [Itogi raboty Ministerstva energetiki za 2018 god i zadachi na 2019 god II // Neft' i Gaz. - 2019. - №2. - S. 153.]

22 Уиллиям Л. Леффрер. Переработка нефти. Пер. с англ. - М.: Олимп - бизнес, 2001. - 367 c. [Uilliyam L. Leffer. Pererabotka nefti. Per. s angl. - M.: Olimp - biznes, 2001. 367 s.]

23 Мановян А.К. Технология первичной переработки нефти и природного газа. - М.: Химия, 2001. - 586 с. [Manovyan A.K. Tekhnologiya pervichnoj pererabotki nefti i prirodnogo gaza. - M.: Himiya, 2001. - 586 s.]

24 Растворители нефтяных высокомолекулярных углеводородных соединений (ВМС) - М.: Технические условия СТО 38281705-003-2013, Федеральное агентство по техническому регулированию и метрологии, ФБУ «Государственный региональный центр стандартизации, метрологии и испытаний, 2013. - 14 с. [Rastvoriteli neftyanyh vysokomolekulyarnyh uglevodorodnyh soedinenij (VMS) - M.: Tekhnicheskie usloviya STO 38281705-003-2013, Federal'noe agentstvo po tekhnicheskomu regulirovaniyu i metrologii, FBU «Gosudarstvennyj regional'nyj centr standartizacii, metrologii i ispytanij, 2013. - 14 s.]

25 Вихревая вакуумно-волновая колонна ВВК-40 - М.: Технические условия СТО 38281705-004-2013. - 37 c. [Vihrevaya vakuumno-volnovaya kolonna VVK-40 - M.: Tekhnicheskie usloviya STO 38281705-004-2013. - 37 s.] 